\title{
3-D Geological Model of the BK16 kimberltie pipe located within the Orapa Kimberlite Field (OKF) in Botswana
}

\author{
Mike C.J. de Wit, Macdonald Kahari, Alistair B. Jeffcoate, R. Theo Hiyoveni, Iuma \\ Martinez, JamesBruchs \\ Tsodilo Resources Ltd, Toronto, Ontario, Canada.mdewit@tsodiloresources.com, mac@tsodiloresources.com, \\ alistair.jeffcoate@tsodiloresources.com, imartinez@tsodiloresources.com, jbruchs@tsodiloresources.com
}

\section{INTRODUCTION}

BK16 is one of the known diamondiferous kimberlites of the Orapa Kimberlite Field ("OKF") in Botswana of at least 83 known kimberlites, and which Tsodilo Resources Ltd ("Tsodilo") is currently evaluating for its ecconimic potential (Fig. 1). AK01 (the Orapa Mine) was dated at 93.1 Ma (Allsopp et al., 1989), and it is presumed that all the kimberlite intrusions of the OKF are of similar post-Karoo age. Of the 83 known kimberlites of the OKF two (2) are currently being mined AK01 (of which AK02 and AK07 were part) (Orapa Mine, Debswana) and AK06 (Karowe Mine, Lucara Diamond Corporation). Other kimberlites in the area that have been mined but are currently on care and maintenace are BK09 and BK12 (Damtshaa Mine, Debswana), BK11 (Firestone Diamonds) and the DK01 and DK02 (Letlhakane Mine, Debswana). However, construction of a new treatment plant is currently underway to retreat the dumps at Letlhakane. Finally BK01 and BK15 are part of the mine plan for the Damtshaa mine to be exploited in the future. The Karowe mine is renowed for its large stones and has produced such notable diamonds as the 1,109 carat 'Lesedi La Rona' and the 813 carat 'Constellation'. The OKF lies on the northern edge of the Central Kalahari Karoo Basin, where the Karoo Supergroup dips very gently to the SSW and laps on to the pre-Karoo high consisting of Archaean and Palaeoproterozoic basement parts of which outcrop within the Makgadikgadi Depression.

The diamondiferous BK16 kimberlite pipe is approximately 5.9 hectares in size at surface, and contains Type IIa diamonds (Tsodilo, 2016). A core drilling campaing in 2015 totalling 3,050 m from 20 holes identified five (5) phases of kimberlite emplacemet that make up the BK16 kimberlite pipe (see below). A geological model based on this program and historical drill information, 51 line kilometers of high resolution ground magnetic survey, and a detailed gravity survey of 441 survey stations was completed.

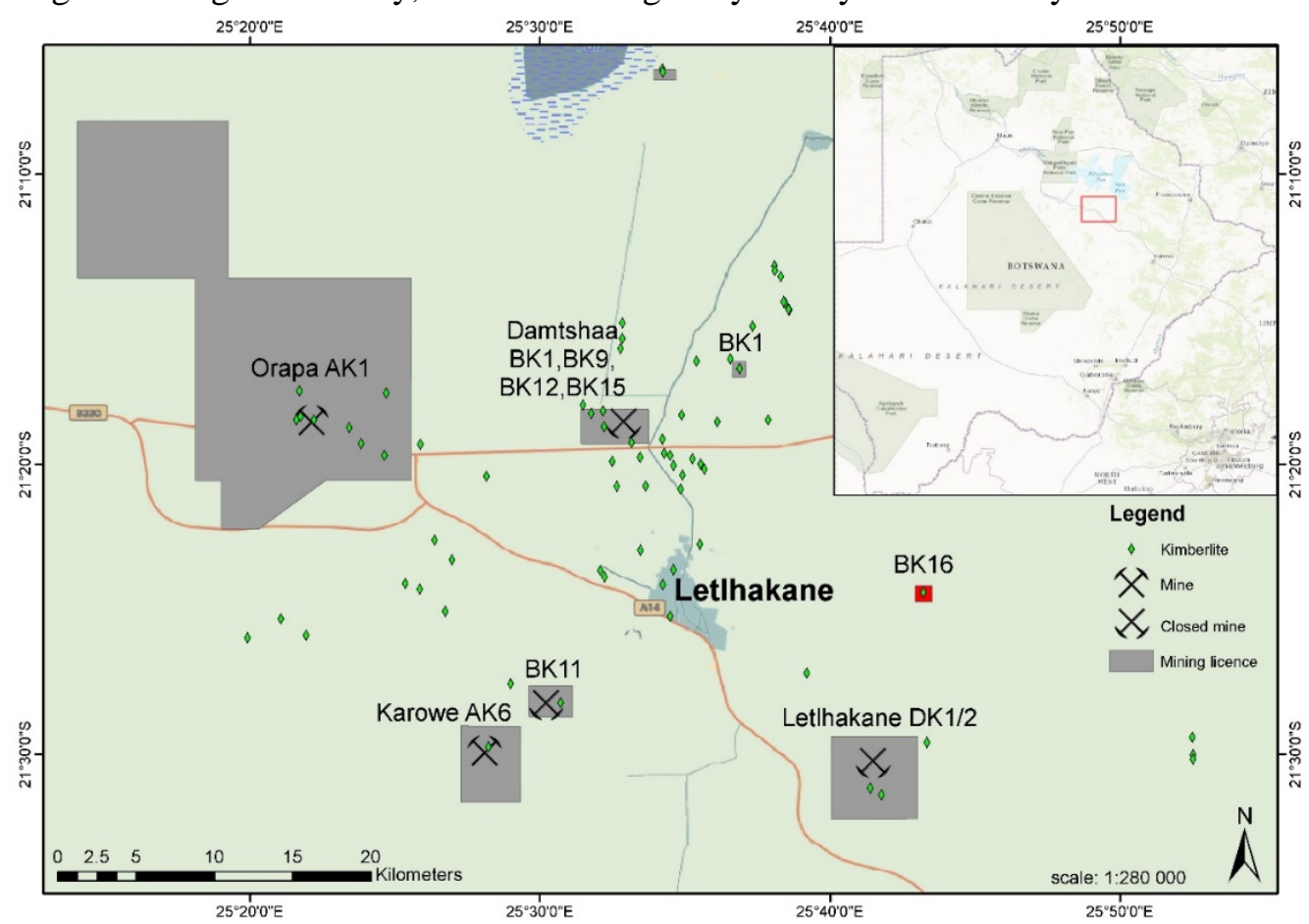

Figure 1. Location of BK16 in relation to the other kimberlites and mines within the OKF. 


\section{BK16 GEOLOGY}

Five (5) different and distinct phases of kimberlite were recognised at BK16 from the recent geological logging and petrograpy of selected samples (Robey, 2015), these phases of kimberlite are as follows:

Kimberlite phases:

1. $\mathrm{CB}=$ Country Rock Contact Breccia. $\mathrm{CB}$ is highly diluted by country rock xenoliths and is thought to represent the embryonic phase of kimberlite emplacement. Bulk Density $=2.52$ $\mathrm{g} / \mathrm{cm}^{3}$.

2. VK2 = Volcaniclastic Kimberlite (Phase 2). VK2 phase is almost black when fresh and occupies the eastern part of the pipe. It has a magmaclastic texture and is a highly serpentinised volcaniclastic kimberlite with variable amounts of relatively unaltered basalt xenoliths. Bulk Density $=2.51 \mathrm{~g} / \mathrm{cm}^{3}$, although when weathered is reduced to $2.31 \mathrm{~g} / \mathrm{cm}^{3}$ (on average).

3. $\quad \mathrm{VK} 3=$ Volcaniclastic Kimberlite (Phase 3). VK3 is generally a grey kimberlite when fresh and forms the western part of the pipe. It is a distinctively speckled volcaniclastic kimberlite due to common but relatively small $(<10 \mathrm{~cm})$ totally altered grey basalt xenoliths. Bulk Density $=2.54$ $\mathrm{g} / \mathrm{cm}^{3}$, although when weathered is reduced to $2.28 \mathrm{~g} / \mathrm{cm}^{3}$ (on average).

4. $\operatorname{VKxxx}=$ Volcaniclastic Kimberlite. VKxxx is a basalt xenolith dominated (up to $88 \%$ by volume) volcaniclastic kimberlite, and occurs dominatly in the central upper part of the pipe. Bulk Density $=2.51 \mathrm{~g} / \mathrm{cm}^{3}$.

5. $\mathrm{CK} 1=$ Coherent Kimberlite CK1 is a minor part of the intrusion and is a coherent kimberlite that was drilled in the southeast part of the pipe. It is a macrocrystic opaque-rich, and monticellite-phlogopite rich kimberlite phase. CK1 is interpreted as an early stage kimberlite dyke. Bulk Density $=2.40 \mathrm{~g} / \mathrm{cm}^{3}$.

The average kimberlite density is $2.48 \mathrm{~g} / \mathrm{cm}^{3}$.

Along with these kimberlite phases there is an overlying younger Kalahari overburden of approximately $25 \mathrm{~m}$, consisting of calcrete and silcrete developed in the Kalahari sands and some limited loose sands at the surface. The country rock of the kimberlite is made up of Karoo age basalts of the Stormberg Lava Group down to between 90 and 120m followed by Ntsane sandstones down to some $170 \mathrm{~m}$ and Lower Karoo mudstones from 170 to a minimum depth of $270 \mathrm{~m}$.

\section{BK16 3D GEOLOGICAL MODEL}

The data from the 20 drill core holes alongside that from the 27 historical boreholes were combined and incorporated into a three-dimensional (3-D) geological model using Gocad software. This geological model includes BK16's different phases and areas of dilution (Fig. 2). This recent Gocad model greatly refined the initial conceptual model reported in a company press release in December 2014 (Tsodilo, 2014).

From this refined model along with a retrospective study of the historical bulk sampling data that includes relative positions of these samples in relation to the zones defined by the geological model, it was possible to establish the following:

1. Of the five key kimberlite phases VK2 and VK3 are the most significant volumetrically and represent some $95 \%$ of the volume of the pipe down to $300 \mathrm{~m}$.

2. The area of the pipe measures 5.9 hectares (ha) at surface, which is a substantial increase from previous estimates of 3.5 ha. A similar increase in surface size was found during exploration of AK06 (Karowe Mine), which increased from 3.3 ha determined in the early 1970s to 9.5 ha when modern exploration techniques were applied in 2003 (Lynn et al., 2014). 


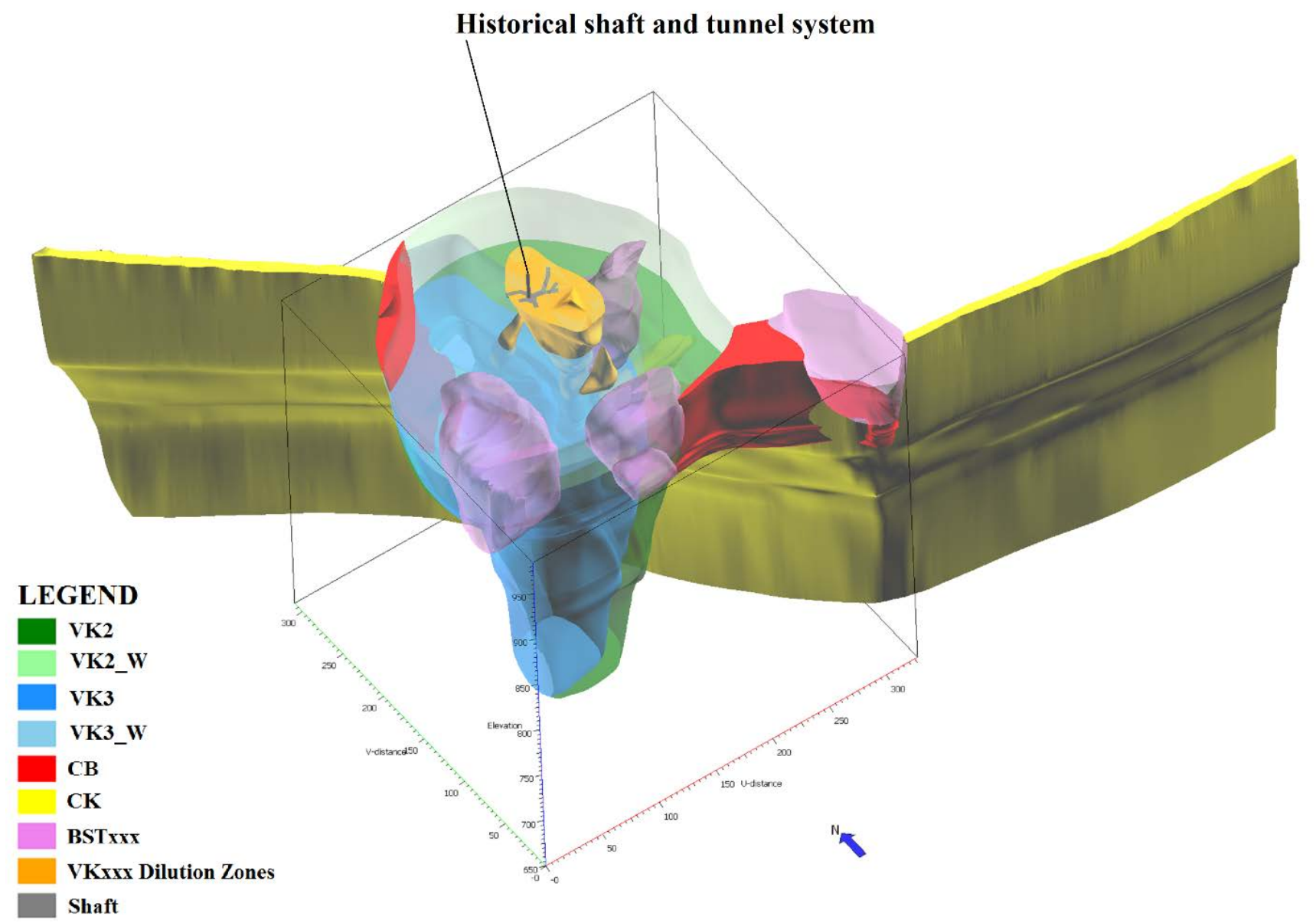

Figure 2. BK16 Geological model below the Kalahari cover overburden, created using Gocad software. It highlights the different kimberlite phases and areas of VKxxx dilution zones (often referred to as basalt breccia). Also shown are the shaft and tunnel systems and their location relative to these VKxxx zones.

\section{References}

Allsopp HL, Bristow JW, Smith CB, Brown R, Gleadow AJW, Kramers JD, Garvie OG (1989) A summary of radiometric dating methods applicable to kimberlites and re-lated rocks. Kimberlites and Related Rocks, vol. 1, Their composition, occurrence, origin and emplacement. Spec.Publ.Geol. Soc. Aust., vol. 14, pp. 343-357.

Lynn M, Nowicki T, Valenta M, Robinson B, Gallagher M, Bolton R, Sexton J (2014) Karowe Diamond Mine Botswana NI 43-101 Independent Technical Report (Amended). Prepared on Behalf of Lucara Diamond Corp.

Robey JvA (2015) Petrography of selected samples taking of BK16 core during the April 2015 logging exercise - Bosoto Pty (Ltd). Internal Report by Rockwise Consulting CC.

Tsodilo Resources Limited Press Release, Dcember $15^{\text {th }}$ (2014) Conceptual Geological Model for BK16. http://www.tsodiloresources.com/i/pdf/2014-12-15_NR-59uXmN.pdf

Tsodilo Resources Limited Press Release, May 31st (2016) Tsodilo Resources Limited Confirms the Presence of Rare and Valuable Type IIa Diamonds in BK16. http://www.tsodiloresources.com/i/pdf/2016-05-31_NR.pdf 